\title{
THE NOTION OF DISABILITY IN SELECTED DOCUMENTS OF INTERNATIONAL ORGANISATIONS
}

\begin{abstract}
The paper focuses on the notion of disability in the documents of selected international organisations. The social model approach to disability has been implemented since the second half of the $20^{\text {th }}$ century and consequently such terms as 'invalid', 'madman', 'dumb', 'cripple', 'paralytic', 'the lame' or 'the blind' were removed from the literature, legal acts, or documents of international organisations. Notions like 'disability', 'disabled person', or 'a person with disability' are considered 'politically correct' now. It is worth highlighting however that great emphasis is put to replace the term 'a disabled person' with the term 'a person with a disability or disabilities" as the latter notion does not refer to the person's characteristics with one adjective only, hence it does not stigmatize him/her either. The trend is reflected in the terminology used in the documents and acts introduced at the international level. Nevertheless, there are still a lot of difficulties with translation into other languages, which is also the Polish case.

Keywords: the notion of disability, person with disability, disabled person, documents of the international organisations.
\end{abstract}

\section{Introduction}

The notion "disability" is difficult to define, interpret, or apply as far as legal, sociological, and medical terminology is concerned. Moreover, linguistic problems might occur when two terms appear i.e. "disabled person" or "person with disability", which is grounded in the fact that disability might take many forms and hence is hard to define clearly and precisely (Golinowska, 2012). In addition, there is no single common definition of disability. There are many terms which refer to disability and numerous methods which may qualify people as disabled both in national or international law, public administration or various studies (for example, statistics, 
good practices, recommendations, or codes of conduct) but also subjective perceptions of people who are disabled. It is worth noting that the group is not homogeneous. Specialist studies refer to people who are physically, mentally, sensorily, or intellectually disabled. Disability might be inborn or acquired either in early childhood or in later years, for example while studying or in full-time employment (Managing Disability in the Workplace. An International Labour Organisation Code of Practice).

Nowadays the following terms are used in the literature, legal acts, and documents of international organisations: "disability", "disabled person", or "person with disability". They have been used only recently and replaced terms such as: "invalid", "madman", "dumb", "cripple", "paralytic", "the lame", or "the blind", which are now considered pejorative, offensive, and humiliating (Krawczyk-Pasłowska, 2010). The term "disability" dates back to ancient times. In Latin the word validus means strong, healthy, whereas the prefix 'in' added to the word meant that a person lacked these features, hence invalidus is considered powerless, ill, and weak (Kwapisz, 2013). Interestingly enough, until the $21^{\text {st }}$ century being considered an invalid was conditioned by a disability acquired during military service. According to a pre-war dictionary (Lam, 1939), an invalid was defined as a weak, senile, or ill person/soldier who was unable to further serve in the army due to his disability or loss of health incurred while in active service.

After World War II, disability was treated as a criterion which distinguished "a healthy person from the invalid" as far as the ability to perform work was concerned (Ulman, 2010). It is worth highlighting here that the term "disability" gives rise to certain consequences. It implies a distinction between disabled and non-disabled people, which generates a kind of dualism insofar that both groups may distance themselves from each other as the problems which disabled people may have are not the concern of those who are not disabled. Nevertheless, the term "disability", if we compare and contrast its previous notions, has evolved and now concerns a much wider group of people who suffer from different kinds of disorder. It may mitigate the marginalisation of such people as it implies incomplete fitness, which allows for seeking and taking advantage of a retained element of fitness (Krawczyk-Pasłowska, 2010). Thus, contrary to the terms used in the past which related to disabled persons, the notion "disability" does not rule out the possibility of personal development and is not exclusively restricted to loss of fitness due to health problems.

Nowadays an equal opportunities policy is being implemented which adopts the social model approach to disability - disabled persons are per- 
ceived as non-disabled actors in society having the same rights as nondisabled citizens of their countries. These changes were introduced in parallel to the development of human rights regulations (Kurowski, 2014). Both paternalistic and isolating protection models in treating disabled persons were abandoned and disabled people started to be treated as ordinary subjects of community life. Said changes in the approach to disability were particularly emphasised in the Madrid Declaration adopted at the European Congress on People with Disabilities which was held on 20-24 March 2002. The postulates encompassed, inter alia (Wapiennik, 2005) treating disabled persons as non-disabled people - consumers and independent citizens - not as charity objects or patients. The postulates did not focus on the disabled persons' individual health impairments or disorders but concentrated on removing barriers, promoting access to the environment, exposing their skills, and creating a friendly and flexible workplace. In addition, the declaration aimed at eliminating unnecessary discrimination in education, employment, and other spheres of life to include persons with a disability in society (Klinik, 2008).

It needs to be highlighted that there are various definitions of disability depending on what they are targeted at. Moreover, the terms have evolved over the years - the emphasis has shifted from health, rehabilitation, and care of the disabled person to the social relations, conditions of work, and need to eliminate discrimination in their daily social and professional lives. Nowadays, great emphasis is placed on the need to replace the term "disabled person" with the term "person with disability or disabilities" as the latter notion does not describe the person's characteristics with a single adjective. Neither does it stigmatize an individual (Galasinski, 2013). Moreover, this trend is reflected in the terminology used in the documents and acts introduced at the international level.

Universal and regional acts of international law are available to resolve the problems faced by people with a disability - they regulate their legal status and issues which concern their functioning in society. The rights of persons with disabilities are frequently seen in the context of human rights; hence, such people are to be granted the same rights as everyone else. As a result, not all acts which regulate their status and position include the term "disability" or "a person with disability'. The terminology in question, which is used in the acts of universal and regional international law adopted by particular international institutions, is further discussed in the paper. Furthermore, the article is devoted only to selected legal acts which attempt to define disability. The description of legal acts focuses on international agreements, which are, apart from the customs and general principles of law, the sources of this law (the so-called "hard law"). Depending on their 
name, there will be a characterisation of e.g. treaties, conventions. The analysis will also be devoted to a number of non-legally binding instruments, e.g. recommendations of international organizations, programs of actions, guidelines, declarations, communications, which are classified as so-called "soft law" (Wyrozumska, 2006).

\section{The United Nations (UN)}

The United Nations is one of the most significant legislators at the international level and has been playing a leading role in shaping universal law for decades (Kurowski, 2010). Since its conception, the United Nations has been involved in solving the problems of the disabled. Demands to protect and support the disabled are indirectly included in the most important legal acts of the organisation - the Charter of the United Nations of 1945, the Universal Declaration of Human Rights of 1948, and the International Covenants on Human Rights of 1966 i.e. the International Covenant on Civil and Political Rights (ICCPR) and the International Covenant on Economic, Social and Cultural Rights (ICESCR).

In the first instance the UN's activities and legislation were not directly targeted at the protection of people with disabilities. Only in the second half of the $20^{\text {th }}$ century were significant acts in this respect adopted by the United Nations General Assembly. They included the Declaration on the Rights of Mentally Retarded Persons of 1971, which stated that mentally retarded persons have the same rights as other human beings. In addition, such persons have the right to appropriate medical care and physical therapy and access to such education, rehabilitation, training, and guidance as to enable them to develop their abilities and skills. On the grounds of that Declaration, mentally retarded persons also obtained the right to economic security, to an adequate standard of living, to perform work or to engage in any other occupation to the fullest possible extent of their capabilities.

On 9 December 1975, the General Assembly of the United Nations formally adopted the Declaration on the Rights of Disabled Persons under cover of Resolution 3447 (XXX). It was the first act to be specifically targeted at all persons with disabilities. The Declaration confirmed that disabled persons should, inter alia, enjoy the right to respect for their human dignity, have the same civil and political rights as all other human beings as well as have the rights to medical, psychological and functional treatment, to economic and social security, and to an appropriate level of living and be able 
to live with their families. The act also defined the term "disabled person". According to the aforementioned declaration, a disabled person is any person unable to ensure by himself or herself, wholly or partly, the necessities of a normal individual and/or social life, as a result of deficiency, either congenital or not, in his or her physical or mental capabilities.

This definition appears to be very wide and therefore can be interpreted relatively freely. However, if contrasted with other definitions which will be presented later in the paper, it seems to be exhaustive and includes many vital elements. Firstly, it points out that a disabled person is a person with a "deficit" of physical and/or mental abilities. The declaration does not mention whether such deficit should be documented or confirmed, for example, by a competent authority and therefore it might be assumed that it covers both biological and legal disability. Secondly, the moment when the disability was acquired is also defined - the document mentions inborn or acquired "deficit". Moreover, according to the document, disability does not have to prevent the person from participation in society but may merely partially hinder that.

It has to be highlighted that at the end of the 1970s measures were implemented to improve the situation of persons with disabilities (Jankowska, 2011/2012). On 16 December 1976 the General Assembly adopted a further resolution (A/RES/31/123), in which the year 1981 was proclaimed as the International Year for Disabled Persons. One year later, on 16 September 1977, the Declaration of Rights of Deaf-Blind Persons was adopted. Additionally, under the provisions of resolution A/RES/37/52 of 3 December 1982, the General Assembly developed the World Programme of Action Concerning Disabled Persons (a non legally binding treaty), which was the chief outcome of the International Year of Disabled Persons. The years between 1983-1992 were called the United Nations Decade of Disabled Persons and were marked by increased efforts to improve the status of people with disabilities. During the International Meeting on Human Resources in the Field of Disability in 1989 the Tallinn Guidelines for Action on Human Resources were laid down, which emphasized a growing need for higher priority to be given to the development of the human resources of disabled persons, especially where training, employment, science and technology are concerned.

Another document of a rather political and ethical character, again nonbinding, was the Standard Rules on the Equalization of Opportunities for Persons with Disabilities drafted by the General Assembly and incorporated in Resolution A/RES/48/96 of 20 December 1993. Interestingly enough, it was the first document to include the expression "persons with disabilities" 
in its title. One of the main objectives of the Standard Rules was to ensure that all people with disabilities, as members of their respective global societies, may exercise the same rights and obligations as others (Quinn, Degener, 2002).

The Standard Rules include an explanation of the term "disability" ("niepełnosprawność" in Polish), which is defined as a great number of different functional limitations occurring in any population in any country of the world. People may be disabled by physical, intellectual or sensory impairment, medical conditions or mental illness. Such impairments, conditions or illnesses may be permanent or transitory in nature. They also define the term 'handicap' ("upośledzenie" in Polish) which is stipulated as the loss or limitation of opportunities to take part in the life of the community on an equal level with others. It describes the encounter between the person with a disability and the environment. The purpose of this term is to emphasize the focus on the shortcomings in the environment and in many organized activities in society, for example, information, communication and education, which prevent persons with disabilities from participating on equal terms.

Adoption of the Standard Rules on the Equalization of Opportunities for Persons with Disabilities might be considered a milestone in a policy solely targeted at persons with disabilities. They stopped being treated as individuals who live at the expense of society. The support models based exclusively on assistance, which meant help provided only to those "stricken by bad fate" and which focused on their physical needs (e.g. the medical model of disability), were dispensed with.

It was clearly pointed out in the aforementioned document that the terminology which refers to disability - in the modern world and in its modern history - is of crucial importance. It was underlined that in the 1970s, established organizations for persons with disabilities along with professionals in the field of disability, reacted strongly against the applied terminology of the time. The main objection was that it relied mostly on a medical and diagnostic approach and completely ignored the imperfections and deficiencies of the surrounding society. In the Standard Rules on the Equalization of Opportunities for Persons with Disabilities, the UN also highlighted that use of the terms "disability" and "handicap" is frequently ambiguous and vague. The adopted distinction between the term "disability" and "handicap" is now in compliance with the International Classification of Impairments, Disabilities, and Handicaps, which was accepted by the World Health Organization in 1980 to ensure a more precise and relevant approach. 
The aforementioned declarations adopted by the United Nations, prove that disability was recognized as one of mankind's problems in the $20^{\text {th }}$ century. Consequently, a shift in the United Nations' actions towards people with disabilities has since been observed, progressively moving from a socialeconomic to a three-pronged policy which includes:

- prevention, aimed at imposing health care, prenatal and postnatal care, education in nutrition, and immunization against communicable diseases;

- rehabilitation, aimed at enabling persons with disabilities to reach and maintain their optimal physical, sensory, intellectual, psychiatric, and social functional levels, hence providing them with the instruments to make their lives more independent;

- equalization of opportunities, aimed at offering to all, particularly to persons with disabilities, access to services, activities, information, and documentation.

This three-pronged policy is targeted at treating people with disabilities as full members of society i.e. enjoying the same rights and freedoms as others.

It is striking that the United Nations Decade of Disabled Persons contributed both to deepening the knowledge and better understanding of the problems encountered by persons with disabilities as well as to elaborating appropriate terminology. Some actions taken were aimed not only at providing them with assistance but also at ensuring their inclusion in society.

One of the most important international acts on the matter is the Convention on the Rights of Persons with Disabilities, adopted on 13 December 2006. It was the first comprehensive human rights treaty of the 21 st century and entered into force on 3 May 2008 (Arnardóttir, Quinn, 2009). The Convention is grounded and works in synergy with preceding international instruments related to persons with disabilities, which were discussed above in the paper: the Standard Rules on the Equalization of Opportunities for Persons with Disabilities from 1994 and the World Programme of Action on Disabled Persons from 1982.

The United Nations Secretary-General, Kofi Annan, said that the landmark disability convention started a new era for around 650 million people worldwide living with disabilities.

The Convention was ratified by the President of the Republic of Poland, Bronisław Komorowski, on 6 September 2012.

The Convention resulted from the need to codify rights granted to persons with disabilities and make those rights legally binding as to-date, as already mentioned - the issues were included in various acts, docu- 
ments and declarations of different importance and range. Some scholars (e.g. Wieruszewski, 2008) point out however that the Convention does not proclaim new rights. For example, Article 5 of the Convention which includes the right of equality and non-discrimination or Article 12 which guarantees equal recognition before law. These rights have already been introduced under the Convention on Human Rights and Fundamental Freedoms and the aforementioned International Covenants on Human Rights of 1966 i.e. the International Covenant on Civil and Political Rights and the International Covenant on Economic, Social, and Cultural Rights. The Convention on the Rights of Persons with Disabilities is the first act of international importance, which fills a legal vacuum in international law in the area of human rights. The act aimed at ensuring that all persons with disabilities can fully enjoy (as in the case of non-disabled people) all human rights and fundamental freedoms as well as ensuring that their inherent dignity is always respected. Furthermore, Article 1 of the Convention, apart from granting the aforementioned rights and freedoms, promotes supporting and protecting them as well as ensuring that the people concerned can fully enjoy the benefits they afford. By way of this treaty the international community recognised the necessity to adopt effective legal measures to combat injustice, discrimination, and violations of those impaired by disability.

It is worth highlighting, as far as the issue in question is concerned, that the UN Convention of 2006, under Article 1, includes its own definition of persons with disability as being those who have long-term physical, mental, intellectual or sensory impairments which in interaction with various barriers may hinder their full and effective participation in society on an equal basis with others.

This definition is very broad as it enumerates various forms of disabilities such as physical, mental, intellectual and/or sensory impairment ones. The phrase "long-term" permits to interpret it quite freely and refers to at least one of the said disorders. The convention does not stipulate how long the disability should last to have a negative impact on the participation of the person with the disability in society or which period of disability can be considered "long-term". Undoubtedly the duration of disability is an important factor in granting legal disability status. Also of course it impacts on the key issue of lifestyle which the definition emphasises, and one question that might be posed in this context is - how can full and effective participation in society be interpreted? - as the concept appears to be somewhat subjective. Nevertheless, according to this definition, possessing legal disability status is not the only condition of being labelled a person 
with disability. The people who face barriers which make their daily lives difficult, such as those who cannot hear well or suffer from chronic depression, are included in the category (Trociuk, 2013). This might be grounded in the fact that the legislature wanted to grant the rights to all persons with a disability i.e. both to those who possess legal disability status as well as those who lack it but consider themselves disabled (biological disability). When we assess the definition as a whole, it appears to be good as it includes an appropriate medical wording of the disability, highlighting its social dimension at the same time. (Kurowski, 2014).

Finally, it is worth mentioning that the United Nations Secretariat for the Convention on the Rights of Persons with Disabilities elaborated some material referring to the act and underscored that the terminology was of crucial importance. It was pointed out that the phrase "person with disability" should be used rather than "handicapped" or "physically or mentally challenged", which may have negative connotations. This institution also highlighted that preferences for terminology may be different both among persons with disabilities and among geographic regions, therefore, the individual wishes of persons with disabilities should be taken into account and respected as much as it is possible.

In addition, a consequence of the changes introduced by the United Nations in the terminology concerning persons with disabilities was the change in the name of the day dedicated to them. The UN General Assembly on 14 October 1992 proclaimed December 3 as the International Day of Disabled Persons, which was first celebrated on 3 December 1992. On 18 December 2007, the General Assembly took the decision to change the name from "International Day of Disabled Persons" to the "International Day of Persons with Disabilities" and the day was duly celebrated under that new name in 2008.

\section{The International Labour Organization (ILO)}

As far as the activities of the International Labour Organization in the issue of persons with disabilities are concerned, the Code of Practice on Managing Disability in the Workplace adopted in 2001 is worth mentioning. Persons with disabilities perform different work at all levels worldwide. However, due to the many barriers and obstacles that exist, many who want to work are not provided with the opportunity to do so. Thus, the main objective of the code was to offer employers at all levels (small and medium sized enterprises, both in the public and private sectors of developing or 
highly industrialised countries) some guidelines to adopt a positive strategy toward disability management. It is worth highlighting that said code is not a binding document which replaces domestic law but includes so-called good practices aimed at ensuring, among other things, that persons with disabilities enjoy the same rights in the workplace as all others.

As regards the notion of the person with disability, which is the primary issue of the present paper, the code also encompasses its own definition of such a person (Managing Disability in the Workplace. An International Labour Organisation Code of Practice, General Provisions point 1.4). Under the code a disabled person is an individual whose prospects of securing, returning to, retaining and advancing in suitable employment are substantially reduced as a result of a duly recognized physical, sensory, intellectual or mental impairment. The quoted term defines disability very broadly and endeavours to cover all of its aspects to ensure that people who have a disability, regardless of extent or character are not discriminated against while searching for and performing work as well as while improving their career opportunities. Nevertheless, the document applies the phrase "disabled person" not "person with disability".

\section{The World Health Organization (WHO)}

One section of the World Health Organisation, the United Nations specialised agency dealing with international health matters and public health, is devoted to the status of people with disabilities. In 1980 the WHO adopted the International Classification of Impairments, Disabilities, and Handicaps (ICIDH) which mentions three key dimensions in that respect biological, functional, and social. As a consequence, three subgroups were distinguished: impairment, disability, and handicap. The said notions were defined by the following expressions: "abnormalities of body structure"; and "a disability is any restriction or lack of ability (resulting from an impairment) to perform an activity in the manner or within the range considered normal for a human being" (Kurowski, 2014), which was repeatedly criticized, for example, due to the fact that medical aspects are over-emphasised and disorders are seen as the source of all difficulties, limitations, and problems experienced by persons with disabilities. That such obstacles might be overcome by medical intervention or rehabilitation, was again a notion not positively assessed by commentators who pointed out that the definition lacks the element which would refer to how the social and physical environment could be adjusted to fit the needs of persons with disabilities. 
Such critical remarks resulted in the issue of a second edition of the ICIDH, entitled the International Classification of Functioning, Disability and Health, commonly known as the ICF, which was adopted by the WHO in 2001. This classification was grounded in the biopsychosocial approach which took into account the relationship between the disorders and limitations of professional and social activities.

The document clearly indicates that the problems of persons with disabilities are not only the problems of social minorities but the problems of mankind as a whole. This approach was based on the conviction that every human being may, during their lifespan, experience a deterioration of his/her health which consequently could result in disability. Therefore, actions taken to prevent or mitigate disability, hence allowing for full participation in society, are indispensable. The approach is comprehensive but differentiated and is justified by the different scope of the problems (biological, functional, or social). Therefore we have various types of disabilities depending on the disorder that prevails in a particular case.

The term "disability" started to be used instead of the term "handicap" during the revision process and it serves as an umbrella term for all three perspectives (body, individual, and societal). Therefore, it was assumed that the WHO, taking into account the status of human health factors, introduced the following notions of disability with specific meanings (ICF, Annexes, point 1) that may be different from their everyday usage (Wilmowska-Pietruszyńska, Bilski, 2014):

- disability is an umbrella term for impairments, activity limitations and participation restrictions. It denotes the negative aspects of the interaction between an individual (with a health condition) and that individual's contextual factors (environmental and personal factors);

- impairment is a loss or abnormality in body structure or physiological function (including mental functions). Abnormality here is used strictly to refer to a significant variation from established statistical norms (i.e. as a deviation from a population mean within measured standard norms) and should be used only in this sense.

As a result, the term 'disability' according to the WHO, may be interpreted as the outcome or result of a complex relationship between an individual's health condition and personal factors, and of the external factors that represent the circumstances in which the individual lives. Disability is not an attribute of an individual, but rather a complex collection of conditions and many of them are created by the social environment in which they live. Hence management of the problem requires social action, and it is the collective responsibility of society at large to make the environmental 
modifications necessary for the full participation of people with disabilities in all areas of social life (Roco \& Bainbridge, 2003: 234).

\section{The Council of Europe}

The Council of Europe is one of the important institutions which introduces standards and harmonizes law at the regional level. Many legal acts were drafted under its auspices, therefore it is frequently underscored by academia that the law of the Council of Europe being a part of public international law compensates for the deficiencies of the latter. The Council of Europe adopts regional international law, hence creates a European ius communis contributing to the harmonisation of law on the Old Continent (Benoît-Rohmer, Klebes, 2006).

One of the earliest laws adopted by the Council of Europe which indirectly refers to disability is the Convention for the Protection of Human Rights and Fundamental Freedoms signed on 4 November 1950. The convention entered into force on 3 September 1953, after having been ratified by the first ten states. In Poland it has been in force since 19 January 1993. The convention is an international agreement which obliges states that belong to the Council of Europe to respect human rights and fundamental freedoms which are not only an important issue in particular countries but the international community as a whole. Article 14 of the Convention introduces the prohibition of discrimination, hence enjoyment of the rights and freedoms stipulated under the Convention should be secured without discrimination grounded in sex, race, colour, language, religion, political or other opinion, national or social origin, association with a national minority, property, birth, or other reasons. The contents of this article do not directly refer to disability; however the European Court of Human Rights (ECHR) in Strasbourg indicated that disability might be "the other" reasons for the discrimination. The Court also included discrimination based on birth (especially if the child is illegitimate), sexual orientation, possession of a residence permit in a particular country (Nowicki, 2013). Moreover, the ECHR in its judgment of 10 March 2011 (application no. 2700/10) highlighted that undoubtedly discrimination on the grounds of disability is also prohibited: "although Article 14 does not expressly list a health status or any medical condition among the protected grounds of discrimination, the Court has recently recognised that a physical disability and various health impairments fall within the scope of this provision". 
The Convention for the Protection of Human Rights and Fundamental Freedoms was extended by social and economic rights by the European Social Charter which was drafted in Turin on 18 October 1961 and then amended by the Protocol amending the European Social Charter (signed in Turin on 21 October 1991). In Poland it came into force on 25 July 1997. The Preamble of the act states that: the aim of the Council of Europe is the achievement of greater unity between its members for the purpose of safeguarding and realising the ideals and principles which are their common heritage and of facilitating their economic and social progress, in particular by the maintenance and further realisation of human rights and fundamental freedoms".

Part I of the Charter obliges the Contracting Parties to accept the policy to attain the conditions in which the nineteen rights and principles may be effectively realised. These rights and principles cover, for example, the right to earn his/her living in an occupation freely entered upon, the right to safe and healthy working conditions, the protection of children and young persons against physical and moral hazards, social, legal, and economic protection of the family, the right to social security. Finally, point 15 refers directly to people with disabilities. It states that disabled persons have the right to vocational training, rehabilitation and resettlement regardless of the origin and nature of their disability. One may pose a question why the term "inwalidztwo", which has a negative overtone, is used in the Polish version of the act adopted by the Council of Europe. It appears to be merely an unfortunate translation of the term "disability" which is sometimes translated as "inwalidztwo" instead of "niepełnosprawność".

In addition, analysing the European Social Charter further, it is worth paying attention to Article 9 in Part II which introduces the right to vocational guidance. This article obliges states to ensure the effective exercise of the right in the form of free assistance while solving problems relating to occupational choice and progress, to all interested, including people with disabilities. This approach enables people with disabilities to search for occupational opportunities, which may help them to have a satisfying social life. Article 10 (1) which prescribes the right to vocational training follows on. Nevertheless, the most obligations concerning the issue in question are imposed on states in Article 15, which stipulates the right of a physically or mentally disabled person to vocational training, rehabilitation, and social resettlement. The article prescribes that the states must take adequate measures to provide training facilities, including where necessary, specialised public or private institutions. They are also supposed to take adequate measures to place disabled persons in employment such as specialised placement 
services, facilities for sheltered employment, and measures to encourage employers to admit disabled persons to employment.

The Council of Europe supports activities, particularly those undertaken at the international level, which are aimed to ensure that disabled persons are treated equally and may integrate into the society. The Council of Europe, however, does not define the term "disability" in its documents. It was further explained in Recommendation R (92)6 of the Committee of Ministers to member states on a coherent policy for people with disabilities that disability is understood as defined by the World Health Organisation (Degener, 1995) as:

- impairment which is understood as any loss or abnormality of psychological, physiological or anatomical structure or functions,

- disability as any restriction or lack (resulting from an impairment) of ability to perform an activity in the manner of or within the range considered normal for a human being,

- limitation in performing social roles, a handicap which means a disadvantage, for a given individual, resulting from an impairment or a disability, that limits or prevents the fulfilment of a role that is normal (depending on age, sex, and social and cultural factors) for that individual.

It was explained further in this recommendation that the handicap depends on the person's relations with his/her environment and is noticeable when such a person encounters cultural, material, and social obstacles, which hinder access to the whole range of services and opportunities available to other citizens. Moreover, the handicap results in the loss of or limitations in the scope of their participation in the community life so they are unable to participate on an equal footing with others. In addition, we cannot treat all persons with disabilities alike as they have different needs or dependence on their disability, thus states should provide access not only to health service or rehabilitation but ensure their full participation in the community life.

The Council of Europe in its subsequent documents describes the aforementioned recommendation as a pioneering one as it has affected the policies aimed at persons with disabilities for over ten years and contributed to new solutions in the area of integration policy both at national and international levels to the benefit of persons with disabilities. The outcome of the aforementioned activities was Recommendation Rec (2006)5 of the Committee of Ministers to member states on the Council of Europe - Action Plan to promote the rights and full participation of people with disabilities in society: improving the quality of life of people with disabilities in Europe 2006-2015. The Council of Europe, while describing its mission in the Ac- 
tion Plan, highlighted that its aims cover human rights, non-discrimination, equal opportunities and full participation of persons with disabilities in both civic and social life.

\section{The European Union}

The European Union while forming disability policy is frequently inspired by the actions taken by the aforementioned international organisations i.e. the United Nations and the Council of Europe. The increased interest of the European Union in disability policy has been observed since the second half of the nineties of the previous century. The EU disability policy aimed at combating regional disparities in that respect in particular EU states and creating open societies accessible for everyone.

At this point it would be worth mentioning that EU primary law does not define the term "disability". Article 10 of the Treaty on the Functioning of the European Union indicates that in defining and implementing EU policies and activities, the Union should aim to combat discrimination based on sex, racial, or ethnic origin, religion or belief, disability, age or sexual orientation. Moreover, Article 19 states that "Without prejudice to the other provisions of the Treaties and within the limits of the powers conferred by them upon the Union, the Council, acting unanimously in accordance with a special legislative procedure and after obtaining the consent of the European Parliament, may take appropriate action to combat discrimination based on sex, racial or ethnic origin, religion or belief, disability, age or sexual orientation". These regulations indicate that disability is treated as one of the grounds of discrimination which the EU wants to combat by means of its law. Disability and related regulations are part of the secondary law of the EU, therefore further analysis concerns it. Due to the variety of legal acts adopted by the European Union, the acts referring to the issue in question will be presented in chronological order.

Communication of the Commission COM(96)406 of 30 July 1996 on Equality of Opportunity for People with Disabilities - a New European Community Disability Strategy, was a pioneering document in the scope of actions for persons with disabilities. Many actions were described therein which were mainly aimed at respecting the autonomy and independence of persons with disabilities and providing support in their endeavours to participate in community life fully, removing barriers to take up active em- 
ployment, adjusting specialised care for persons with disabilities, removing barriers in infrastructure and creating new work opportunities, scientific, cultural and sports institutions, and facilities.

The Treaty of Amsterdam signed on 2 October 1997 was a milestone in EU policy for persons with disabilities. Article 6a included provisions concerning the prohibition on discrimination based on disability: "Without prejudice to the other provisions of this Treaty and within the limits of the powers conferred by it upon the Community, the Council, acting unanimously on a proposal from the Commission and after consulting the European Parliament, may take appropriate action to combat discrimination based on sex, racial or ethnic origin, religion or belief, disability, age or sexual orientation". In fact it was one of the first treaties in which the European Union directly referred to the issue of disability although the term was not defined therein.

The European Union in the Communication of the Commission COM (2000)284 of 12 May 2000 "Towards a barrier free Europe for people with disabilities" implemented its action plans concerning persons with disabilities and presented both the strategy for actions in that respect and made a commitment to support any initiatives concerning persons with disabilities. In the same year the Council enacted the Directive 2000/78/EC of 27 November 2000 establishing a general framework for equal treatment in employment and occupation, which is considered a part of the common basis for anti-discrimination law in the European Union. The directive sets minimal standards by virtue of which EU member states agree to provide extended legal protection; i.e. the states cannot introduce solutions which are less favourable than those stipulated in the directive (Kopczyk, 2013). In the Preamble of the act the Council highlighted that adopting measures which take into account the needs of persons with disabilities in the workplace is one of the most important factors to combat discrimination based on disability (Kołaczek, 2008). The communication also identified the need to adopt effective and practical measures to adjust workplaces to meet the needs of persons with disabilities like adapting the workplace or equipment, adjusting working time, or allocating tasks accordingly. The Directive of the Council 2000/78/EC does not define disability as such. Article 2 merely mentions the concept as the source of direct ("when one person is treated less favourably than another is, has been or would be treated in a comparable situation") or indirect ("where an apparently neutral provision, criterion or practice would put persons having a particular religion or belief, a particular disability, a particular age, or a particular sexual orientation at a particular disadvantage compared with other per- 
sons") discrimination. Nevertheless, the Court of Justice of the European Union (CJEU) formed some judgements on the grounds of this directive in which it was stated, among other things, how the term 'disability' should be interpreted. For example, in the Judgment of the Court (Grand Chamber) of 11 July 2006 (C-13/05) Sonia Chacón Navas v Eurest Colectividades SA, it was underlined that although the term 'disability' within the meaning of the Council Directive 2000/78 is understood as referring to a limitation which results in particular from physical, mental, or psychological impairments and which hinders the participation of the person concerned in professional life, the two concepts "disability" and "sickness" cannot therefore simply be treated as being the same. The term "disability" used in Article 1 of the Directive was intentionally chosen by the legislator to distinguish it from "sickness". Moreover, the importance given to the measures which are supposed to adjust working conditions depending on the kind of disability implies that the legislature assumed that there are long-term obstacles which prevent persons with disabilities from active participation in their professional life.

The analysis of the aforementioned judgement confirms that the Court of Justice of the European Union treats disability as a long-lasting pathological state resulting in physical, mental, or psychological impairments which may hinder full participation in social and professional life.

The European Union designated 2003 as the European Year of People with Disabilities (Council Decision 2001/903/EU of 3 December 2001 on the European Year of People with Disabilities 2003) being aware that, despite numerous actions taken, persons with disabilities still encounter barriers and are discriminated against in many European societies. Since then the European Union has been implementing disability policy at different levels, regulating many aspects of life, like access for persons with disabilities to knowledge-based society, ensuring equal opportunities for pupils and students with disabilities in education and professional training or access to cultural infrastructure or cultural activities.

On 5 July 2006 the European Parliament and the Council adopted Regulation (EC) 1107/2006 concerning the rights of disabled persons and persons with reduced mobility when travelling by air. It was highlighted in its Preamble that the single market for air services should benefit citizens in general. To accomplish the set objectives, appropriate assistance should therefore be provided to persons with disabilities according to their needs both at airports and on board by employing indispensable staff and providing appropriate equipment. Moreover, bearing in mind social integration, which is frequently emphasised in the EU documents, those people should 
receive such assistance without additional charge. It is worth underscoring here that the discussed act is one of the few EU documents which, for the purposes of the regulation, defines the terms "disabled person" and "person with reduced mobility". Under Article 2a a "disabled person" or "person with reduced mobility" is defined as "any person whose mobility when using transport is reduced due to any physical disability (sensory or locomotor, permanent or temporary), intellectual disability or impairment, or any other cause of disability, or age, and whose situation needs appropriate attention and the adaptation to his or her particular needs of the service made available to all passengers". Disability in this act is treated as a kind of barrier resulting from a permanent or temporary handicap, either of a physical or intellectual character or impairment, which hinders using transport. Taking into consideration the purposes for which this definition was provided, it is worth underlining its clarity and multidimensionality. One may merely assume that it refers to dysfunctions which have been stated under the law in force in a particular EU member state. The European Union appears to support a social disability model, emphasising the need to ensure that persons with impairments actively participate in community life.

Currently, the disability issue is present in many EU programmes. The Rights, Equality, and Citizenship Programme for the period 2014 to 2020 (Regulation (EU) 1381/2013 of the European Parliament and of the Council of 17 December 2013 establishing a Rights, Equality and Citizenship Programme for the period 2014 to 2020) may serve as an example here. The activities taken for persons with disabilities within the European Union are solid and regular although not all of them are legally binding as they take the form of communications, opinions, or recommendations. Nevertheless, they can stimulate EU institutions and member states to take actions aimed at persons with disability.

\section{Conclusions}

As becomes apparent from the above analysis, the definition of physical or mental disability varies depending on the international organisation which takes action to help persons with a disability. However, there are some elements which occur in all definitions i.e. the forms of disability such as physical or mental. Most of the terms presented highlight that disability negatively affects an individual's functioning in society, hence generating problems in everyday routine (Kowal, 2006), finding work, or promoting personal development. Therefore, it is frequently underscored by the in- 
ternational community that the notion of disability should cover all three perspectives - physical, individual, and social. In addition, it is pointed out that there is a need to define various terms precisely as the acts of international law are translated into numerous languages which may result in terminological inaccuracies (ICF International Classification of Functioning, Disability and Health) despite the fact that the same aim exists behind all of the definitions.

Such inaccuracies also occur in Polish translations of international acts. The title "The Convention on the Rights of Persons with Disabilities" was translated as "Konwencja o prawach osób niepełnosprawnych" instead of "Konwencja o prawach osób z niepełnosprawnościami". The Polish version appears to use the term "disabled persons". It is worth mentioning however that in many acts passed by the Polish legislature which refer to people with disabilities, the terminology differs significantly from that included in international law. For example: the Act of 27 August 1997 on the Professional and Social Rehabilitation and Employment of Disabled People; the Charter of Rights for Persons with Disabilities, approved by the Sejm of the Republic of Poland on 1 August 1997; and the Ordinance of the Minister of Economy, Labour and Social Policy dated 15 July 2003 on the Assessment of Work Ability and Disability. These acts all use, in Polish, the term 'disabled person'.

Also clearly apparent from the above discussion, is that the use of language and terms describing persons with disabilities have changed over time. The acts or documents of current public international law employ the term 'disability' to denote a multidimensional phenomenon which is grounded in the interaction between people and their physical and social environment. Due to various reasons, when referring to individuals, some people use the term 'people with disabilities' while others prefer the notion of 'disabled people'. Hence it is a vital principle to remember that people with disabilities have the right to be called as they wish but disrespectful language can make them feel excluded and can be a barrier to their full participation in society. Therefore, it is of key importance to distinguish between outdated and respectful language (see Table 1 . below).

Table 1

\section{Different descriptions of disability}

\begin{tabular}{|l|l|l|}
\hline \multicolumn{1}{|c|}{ Disability } & \multicolumn{1}{|c|}{ Out-dated language } & \multicolumn{1}{c|}{ Respectful language } \\
\hline $\begin{array}{l}\text { blind or visual } \\
\text { impairment }\end{array}$ & dumb, invalid & $\begin{array}{l}\text { blind/visually impaired, } \\
\text { person who is blind/ } \\
\text { visually impaired }\end{array}$ \\
\hline
\end{tabular}




\begin{tabular}{|l|l|l|}
\hline \multicolumn{1}{|c|}{ Disability } & \multicolumn{1}{|c|}{ Out-dated language } & \multicolumn{1}{|c|}{ Respectful language } \\
\hline deaf or hearing impairment & $\begin{array}{l}\text { invalid, deaf-and-dumb, } \\
\text { deaf-mute }\end{array}$ & $\begin{array}{l}\text { deaf or hard-of-hearing, } \\
\text { person who is deaf or hard } \\
\text { of hearing }\end{array}$ \\
\hline $\begin{array}{l}\text { speech/communication } \\
\text { disability }\end{array}$ & dumb, "one who talks bad" & $\begin{array}{l}\text { person with a speech / } \\
\text { communication disability }\end{array}$ \\
\hline learning disability & $\begin{array}{l}\text { retarded, slow, "specialed" } \\
\text { braindamaged, }\end{array}$ & $\begin{array}{l}\text { learning disability, cognitive } \\
\text { disability, person with } \\
\text { a learning or cognitive } \\
\text { disability }\end{array}$ \\
\hline mental health disability & $\begin{array}{l}\text { hyper-sensitive, psycho, } \\
\text { crazy, insane, wacko, nuts }\end{array}$ & $\begin{array}{l}\text { person with a psychiatric } \\
\text { disability, person with } \\
\text { a mental health disability }\end{array}$ \\
\hline mobility/physical disability & $\begin{array}{l}\text { handicapped, physically } \\
\text { challenged, "special", } \\
\text { deformed, cripple, } \\
\text { gimp, spastic, spaz, } \\
\text { wheelchairbound, lame }\end{array}$ & $\begin{array}{l}\text { wheelchair user, physically } \\
\text { disabled, person with } \\
\text { a mobility or physical } \\
\text { disability }\end{array}$ \\
\hline short stature, little person & emotionally disturbed & $\begin{array}{l}\text { dwarf, midget } \\
\text { emotionally disabled, } \\
\text { disability }\end{array}$ \\
\hline cognith an emotional \\
\hline health conditions
\end{tabular}

Source: Respectful Disability Language: Here's What's Up!, www.miusa.org/sites/default /files/documents/resource/Respectful\%20Disability\%20Language.pdf.

The analysis of the acts enacted by the international organisations presented above proves that disability constitutes an important element of their activities. The main aim is to provide opportunities to live in decent conditions and participate actively in professional and social lives and to ensure that persons with disabilities are not discriminated against. The activities of these institutions have stimulated numerous European states to take and/or intensify their actions in the area of disability. The acts discussed above, either binding or not, show that there is no single definition of "disability" 
that is exploited by all EU member states - which may have serious consequences. A person who has been granted disability status in one EU member state may not be granted this status in another EU country. In addition, as many scholars underscore, there exist various definitions of "disability" which are used for different purposes (like healthcare, professional and social rehabilitation, employment or education), which may also lead to confusion and misinterpretation.

\section{R E F E R E N C E S}

\section{Legal Sources}

Charter of the United Nations of 26 June 1945.

Code of Practice on Managing Disability in the Workplace, 2001.

Council Decision 2001/903/WE of 3 December 2001 on the European Year of People with Disabilities 2003.

Communication of the Commission COM(96)406 of 30 July 1996 r. on Equality of Opportunity for People with Disabilities - a New European Community Disability Strategy.

Communication of the Commission $\operatorname{COM}(2000) 284$ of 12 May 2000 "Towards a barrier free Europe for people with disabilities".

Convention for the Protection of Human Rights and Fundamental Freedoms signed on 4 November 1950.

Convention on the Rights of Persons with Disabilities of 13 December 2006.

Declaration on the Rights of Mentally Retarded Persons, 1971.

Directive 2000/78/EC of 27 November 2000 establishing a general framework for equal treatment in employment and occupation.

European Social Charter of 18 October 1961.

Recommendation R(92)6 of the Committee of Ministers to member states on a coherent policy for people with disabilities.

Recommendation Rec(2006)5 of the Committee of Ministers to member states on the Council of Europe - Action Plan to promote the rights and full participation of people with disabilities in society: improving the quality of life of people with disabilities in Europe 2006-2015.

Regulation (EC) 1107/2006 of the European Parliament and of the Council of 5 July 2006 concerning the rights of disabled persons and persons with reduced mobility when travelling by air.

Regulation (EU) 1381/2013 of the European Parliament and of the Council of 17 December 2013 establishing a Rights, Equality and Citizenship Programme for the period 2014 to 2020 .

Resolution 3447 (XXX) of 9 December 1975, Declaration on the Rights of Disabled Persons. 
Standard Rules on the Equalization of Opportunities for Persons with Disabilities elaborated by The General Assembly as a part of resolution (A/RES/48/96) of 20 December 1993.

Tallinn Guidelines for Action on Human Resources Development in the Field of Disability, Adopted by G/A/RES 44/70 of 15 March 1990.

The International Covenants on Human Rights from 1966: International Covenant on Civil and Political Rights (ICCPR) and the International Covenant on Economic, Social and Cultural Rights (ICESCR).

\section{Books and articles}

Arnardóttir M., Quinn G., 2009. The UN Convention on the Rights of Persons with Disabilities. European and Scandinavian Perspectives, Leiden - Boston, pp. 319.

Benoît-Rohmer F., Klebes H., 2006. Prawo Rady Europy. W stronę ogólnoeuropejskiej przestrzeni, Warsaw, p. 92, 138.

Degener T., Disabled persons and human rights: the legal Framework, (in:) T. Degner, Y. Koster-Dreese (ed.), 1995 Human Rights and Disabled Persons. Essays and Relevant Human Rights Instruments, Dordrecht - Boston - London, p. 35 .

Galasiński D., 2013. Osoby niepełnosprawne czy z niepełnosprawnościa?, Niepełnosprawność - zagadnienia, problemy, rozwiązania, Vol IV (9), p. 3-6.

Golinowska S., 2012. (ed.) Instytucjonalne, zdrowotne $i$ spoteczne determinanty niepelnosprawności, Warsaw, p. 31.

ICF. International Classification of Functioning, Disability and Health, World Health Organization, Geneva 2001, p. 20.

Jankowska M., 2011/2012. Prawa osób niepełnosprawnych w międzynarodowych aktach prawnych, Niepełnosprawność - zagadnienia, problemy, rozwiązania 2011/2012, Vol. I/2011 (1), I/2012 (2), p. 36.

Klinik A. (ed.), 2008. W strone podmiotowości osób niepetnosprawnych. Tom IV serii: Problemy edukacji, rehabilitacji i socjalizacji osób niepetnosprawnych, Kraków, pp. 196.

Kołaczek B., Zakaz dyskryminacji osób niepelnosprawnych, Polityka Społeczna 2008, Vol. 8, p. 4-8.

Kopczyk R., 2013. Zakaz dyskryminacji w sporcie w prawie Unii Europejskiej, Warsaw, p. 118.

Kowal E., 2006. Problemy życia codziennego osób niepetnosprawnych, (in:) H. Ochonczenko, A. Nowicka, Potrzeby osób niepetnosprawnych w warunkach globalnych przemian społeczno-gospodarczych, Cracow, p. 77-87.

Krawczyk-Pasłowska E., 2010. Niepełnosprawność. Bariery i szanse, Cracow, p. 7.

Kurowski K., 2010. Ewolucja regulacji prawnych Organizacji Narodów Zjednoczonych w zakresie problematyki praw osób niepetnosprawnych, (in:) D. Podgórska-Jachnik (ed.), Problemy orzecznictwa i reprezentacji osób niepetnospraw- 
nych. Ruch na rzecz lepszej przyszłości osób niepełnosprawnych. Tom II, Łódź, p. 53-71.

Kurowski K., 2014. Wolności i prawa człowieka i obywatela z perspektywy osób $z$ niepelnosprawnościami, Warsaw, p. 7-8.

Kwapisz K., 2013. Ustawa o emeryturach $i$ rentach z Funduszu Ubezpieczeń Społecznych. Komentarz, Warsaw, p. 52.

Lam S., (1939) Słownik wyrazów obcych, Warsaw.

Nowicki M. A., 2013. Wokól Konwencji Europejskiej. Komentarz do Europejskiej Konwencji Praw Człowieka, Warsaw, p. 958.

Opracowanie Międzynarodowego Biura Pracy w Genewie pt. Managing disability in the workplace. An ILO code of practice, Polish version Zarzadzanie niepetnosprawnościa w miejscu pracy, Warsaw 2013, p. III.

Quinn G., Degener T (ed.), 2002. Human Rights and Disability. The Current Use and Future Potential of United Nations Human Rights Instruments in the Context of Disability, New York, Geneva, p. 22-23.

Roco M. C., Bainbridge W.S., 2003. Converging Technologies for Improving Human Performance. Nanotechnology, Biotechnology, Information Technology and Cognitive Science, Springer Netherlands, p. 234.

Trociuk S. (ed.), 2013. Konwencja o prawach osób niepelnosprawnych. Poradnik RPO, Warsaw, p. 12.

Ulman P., 2010. Problem niepetnosprawności w krajach UE. Analiza porównawcza, Nierówności Społeczne a Wzrost Gospodarczy, Vol. 16, p. 314.

Wapiennik E., 2005. Działania Unii Europejskiej na rzecz osób z niepełnosprawnościa, (in:) D. Gorajewska (ed.), Społeczeństwo równych szans - tendencje i kierunki zmian, Warsaw, pp. 39-59.

Wieruszewski R., 2008. Konwencja Narodów Zjednoczonych o prawach osób niepełnosprawnych w polskim porzadku prawnym, (in:) A. M. Waszkielewicz (ed.), Polska droga do Konwencji o prawach osób niepelnosprawnych ONZ, Cracow, p. 10.

Wilmowska-Pietruszyńska A., Bilski D., 2014. Międzynarodowa klasyfikacja Funkcjonowania, Niepetnosprawności i Zdrowia, Orzecznictwo Lekarskie 2014, No 9 (1), p. 24.

Wyrozumska A., 2006. Umowy międzynarodowe. Teoria i praktyka, Warsaw, pp. $681-689$. 